\title{
Specialty Investigation Against Corruption Crime by the Corruption Eradication Commission
}

\author{
Julianus Edwin Latupeirissa ${ }^{1} \quad$ M. Syukri Akub ${ }^{2} \quad$ M. Said Karim ${ }^{2}$ Irwansyah $^{2}$ \\ 1.Graduate School, Hasanuddin University, Indonesia \\ 2.Professor, Faculty of Law, Hasanuddin University, Indonesia
}

\begin{abstract}
The implementation of the investigation and investigation carried out by the Corruption Eradication Commission has special authority that is different from the police and prosecutors who are very helpful to the Corruption Eradication Commission in the investigation process but it creates disharmony among fellow law enforcement agencies so that they seem egocentric between institutions and cannot fulfill the rights of suspects and the protection of human rights in the implementation of some privileges of the investigation process carried out and for the harmonious implementation of investigations of corruption that have been regulated in various laws and regulations, it must harmonize all the investigative authorities so that there is no conflict between law enforcement agencies.
\end{abstract}

Keywords: corruption crime, corruption eradication commission, investigation.

DOI: $10.7176 / J L P G / 87-17$

Publication date:July $31^{\text {st }} 2019$

\section{Introduction}

The 1945 Constitution of the Republic of Indonesia in the Third Amendment of 2001 namely Article 1 paragraph (3) affirms that Indonesia is a state based on law (rechtstaat), not based on power (machtsstaat). One of the reasons for the establishment of Law Number 8 Year 1981 concerning the Criminal Procedure Code (KUHAP) is to replace Herziene Inlands Reglement (HIR) because of the existence of Human Rights. The Criminal Procedure Code contains provisions on criminal proceedings that provide better protection against human rights compared to the provisions of criminal proceedings in the HIR. Criminal law according to Lilik Mulyadi includes (1) legal regulations that regulate, administer, and maintain the existence of criminal provisions in Criminal Material (Materieel Strafrecht) in order to find, find, and obtain material truth or the truth; (2) Legal regulations governing the manner and process of making decisions by the Judge; (3) Legal regulations governing the implementation stage rather than decisions that have been taken.

The Criminal Procedure Code is expected to be a guideline for carrying out justice for courts in the general court and the Supreme Court by regulating rights and obligations for those in criminal proceedings, so that the basis of the rule of law can be enforced. ${ }^{1}$ The purpose of the Criminal Procedure Law is "to seek and obtain or at least approach material truth, is the truth as complete as possible from a criminal case by applying the provisions of the Criminal Procedure Code honestly and precisely, with the aim of finding out who the perpetrator can be charged with violation of law, and subsequently request an examination and decision from the court to find out whether it has been proven that a criminal offense has been committed and whether the accused person can be blamed". 2

Barda Nawawi Arief ${ }^{3}$ argues that the Criminal Justice System is essentially identical to the criminal law enforcement system. The law enforcement system is basically a system of power/authority to enforce the law. The power/authority to enforce this law can be identified with the term judicial power. Because the Criminal Justice System is essentially also identified with the judicial power system in the field of criminal law which is implemented/realized in four sub-systems namely:

1) The power of investigation by investigative institutions.

2) The power of prosecution by the public prosecuting agency.

3) The power of adjudicates/decreases decisions by judicial bodies and,

4) The power of implementation of criminal law by the executor of execution.

Penalty on the one hand is not only intended to give suffering to offenders or make deterrent, but on the other hand also to make offenders able to return to live in society as appropriate. ${ }^{4}$ For the sake of carrying out the

\footnotetext{
${ }^{1}$ M. Said Karim, Ganti Kerugian Terhadap Korban Penangkapan yang Tidak Sah dalam Proses Peradilan Pidana, Pustaka Pena Press, Makassar, 2019, p. 1

${ }^{2}$ Anonimous, Pedoman Pelaksanaan Kitab Undang-Undang Hukum Acara Pidana, Penerbit Departemen Kehakiman Republik Indonesia, 1982, p. 1

${ }^{3}$ Barda Nawawi Arief, Kapita Selekta Hukum Pidana tentang Sistem Peradilan Pidana Terpadu, BP Universitas Diponegoro Semarang, 2007, p. 19, 20, and 26

${ }^{4}$ Andi Sofyan and Nur Azisa, Hukum Pidana, Pustaka Pena Press, Makassar, 2016, p. 83; see also Tolib Setiady, Pokok-Pokok Hukum Panitensier Indonesia, Alfabeta, Bandung, 2010, p. 21
} 
interest of investigating criminal acts, the law gives authority to investigators and public prosecutors to carry out acts of forced effort in the form of arrest, detention, searches, confiscations and so on. Every forced effort made by an investigator or public prosecutor against a suspect is essentially a treatment that is (a) forced action which is based on the law in the interest of the examination of criminal acts that are suspected of the suspect; (b) as a forced act justified by law, every forced act is by itself a deprivation of freedom and freedom as well as restrictions on human rights.

The rights of citizens to obtain protection are positive rights which in the sense must be fulfilled actively and maximally by the state towards its citizens. ${ }^{1}$ Guaranteed protection of the integrity of human dignity is contained in the principles, and is used as a guideline in understanding and interpreting the meaning of the provisions of the articles of the Criminal Procedure Code. Protection of human rights is regulated in the provisions of Article 50 to Article 68 of the Criminal Procedure Code concerning the rights of suspects and defendants among them:

1. The right of a suspect to immediately get an examination (Article 50 paragraph (1));

2. The right of the suspect of the case is immediately submitted to the court (Article 50 (2));

3. The right of the suspect to get a defense and be clearly notified in a language that is understood about what is alleged to be at the time the examination begins (Article 51 letter a);

4. At the level of investigation, the suspect has the right to give information freely to the investigator (Article 52);

5. The right of a suspect to receive assistance from an interpreter at any time (Article 53 paragraph (1)); and in the case of a deaf or deaf suspect (Article 53 paragraph (2));

6. The right to receive legal assistance from its legal counsel during the time and at each level of inspection (Article 54);

7. The right of a suspect to choose his own legal counsel (Article 55);

8. The right of a suspect to get a designated legal advisor, in the case of not having his own legal counsel suspected/charged with a criminal offense punishable by death, 15 years or more, an incapable suspect who is threatened with a sentence of five years or more (Article 56 paragraph (1)), and the right to obtain free legal assistance (Article 56 paragraph (2));

9. The right of detained suspects to contact their legal counsel (Article 57 paragraph (1));

10. The right to receive a private doctor's visit (Article 58);

11. The right to be notified of detention of himself at all levels of examination to his family (Article 59);

12. The right to contact and receive family visits is guaranteed for suspension or attempts to obtain legal assistance (Article 60);

13. Rights directly or through the intercession of legal counsel contact and receive family visits in relation to work interests (Article 61);

14. The right to send letters to legal counsel and receive letters from legal counsel or relatives (Article 62 paragraph (1));

15. The right to contact and receive visits from clergy (Article 63);

16. The right to seek or submit a witness and or someone who has special expertise to provide information that can benefit him (Article 65);

17. Rights are not burdened with the obligation of proof (Article 66); and

18. The right of a suspect to sue for compensation and rehabilitation (Article 68).

In relation to the handling of corruption cases, some of the important points contained in the articles of the Universal Declaration of Human Rights which were initiated on December 10, 1948 are:

1) Equal rights to life;

2) Equality of rights to be free from torture or cruel, inhuman treatment or punishment;

3) Equal rights to obtain legal recognition and freedom without differentiation based on politics, religion, taste or anything else;

4) Equal rights to get a position before the law, legal protection anywhere, and personal legal recognition anywhere;

5) Equal rights for effective legal forgiveness;

6) Equal rights to be free from arbitrary arrest, detention or disposal;

7) Equal rights for fair trials and hearings conducted by independent and impartial courts;

8) The equality of rights to the presumption of being innocent;

9) Equal rights to be free from arbitrary interference with privacy, family, residence and letters;

10) Equal rights to be free from attacks on honor and good name;

\footnotetext{
${ }^{1}$ Nur Azisa, Nilai Keadilah Terhadap Jaminan Kompensasi Bagi Korban Kejahatan (Sebuah Kajian Filospfis - Normatif), Pustaka Pena
} Press, Makassar, 2016, p. 10 
11) Equal rights to legal protection against such attacks;

12) Equal rights to move freely, to obtain asylum, to marry and form a family; and

13) Equality of rights to be free to think, be aware and be religious and express opinions.

Jack Donnelly in Siobhan McInerney-Lankford ${ }^{1}$ argues that literally Human Rights are rights owned by someone because he is human. Maurice Cranston was also quoted by Siobhan Mc Inerney ${ }^{2}$ argues that Human Rights are "... a universal moral right, something which all men everywhere, at all times ought to have, something of which no onemay be deprived without a grave affont to justice, something which is owing to every human being simply because he is human."

In the legal literature, it has also been realized that a right sometimes has weak power to be carried out in accordance with the purpose for which rights are granted. Among other things, this was revealed by L.J. van Apeldoorn, who quoted Max Stirner's words that, "a sum of power is more beneficial than a pact". ${ }^{3}$ Adolfo Beria views corruption as a world phenomenon, its existence follows the history of the country, the economy of the country and harms the interests of society, ${ }^{4}$ man himself. ${ }^{5}$ Furthermore Adolfo Beria stated that:

"There is no primordial indigenous culture without its phenomena of corruption; there is no system (from that of USA to that of Japan) which is free from vast areas of corruption; there is no centre of government (from the prairies of America to the communist collectivizations) which has not been vitiated or distorted by corruption; there is no religion (Eastern, Judaic-Christian or Islamic) which has not had to confront evils connected to corruption; there is no Empire (be it Persian, Roman, British or Soviet) which has not experienced and has not been damaged by corruption". ${ }^{6}$

Corruption in Indonesia continues to show an increase from year to year. Both of the number of cases that occur and the amount of state financial losses. The quality of criminal acts of corruption committed is also increasingly systematic with a scope that enters all aspects of people's lives. Corruption weighs on the Indonesian people, especially the poor. Corruption also creates high macro-economic risks, endangers financial stability, compromises security and law and public order, and above all, corruption undermines the legitimacy and credibility of the state in the eyes of the people, ${ }^{7}$ because Corruption is literally decay, ugliness, depravity, dishonesty, can be ignored, immoral, deviations from chastity, insulting or defamatory words or sayings, ${ }^{8}$ and the actions of someone who is detrimental to the country's finances and which makes the government apparatus ineffective, efficient, clean and authoritative. ${ }^{9}$ Corruption is not only the health of the national economy, but also the social order and life and stages of development that have been achieved, where and whenever he emerges. ${ }^{10}$

Recognizing the complexity of corruption in the midst of a multidimensional crisis and a definite real threat, namely the impact of the crime of corruption itself, corruption can be categorized as a national problem that must be dealt with seriously through the rare balance that firm and clear by involving all the potential that exists in the community especially the government and the law enforcers. ${ }^{11}$ Based on data from the Corruption Eradication Commission (KPK) shows that in 2015 there were 87 cases that had been investigated by KPK investigators, in 2016 there were 96 cases that had been investigated by KPK investigators, in 2017 there were 123 cases that had been investigated by KPK, and in 2018 there were 164 cases. $^{12}$

Considering that many corruption cases were revealed and handled by the KPK, in the provisions of Article 38 paragraph (1) of Law 30 Year 2002 concerning the Corruption Eradication Commission stated that "all authorities relating to investigations, investigations and prosecutions are stipulated in Law Number 8 Year 1981 the Criminal Procedure Law also applied to investigators, investigators and public prosecutors in the Corruption Eradication Commission".

If you look at the provisions stipulated in the Criminal Procedure Code and/or Law Number 31 Year 1999, the Law Number 20 Year 2001 concerning the Eradication of Corruption Crime and/or Law Number 30 Year 2002 concerning the Corruption Eradication Commission is equally regulating about investigation, but in fact found different arrangements in the implementation of the investigation, which is often used by the KPK is Law

\footnotetext{
Jack Donnelly, 2003, Universal Human Rights in Theory and Practice, $2^{\text {nd }}$ ed., Cornel University Press, Itacha, p. 7 in Mc InenrneyLankford Siobhan, Sano Otto-Hans., Human Rights Indicators in Development: An Introduction, The World Bank, Washington D.C., PCS Country Services, Nordic Trust Fund, p. 3

${ }^{2}$ Maurice Cranston, 1973, What Are Human Rights, Taplinger Publishing Co., p. 36.

${ }^{3}$ L.J. van Apeldoorn, Pengantar Ilmu Hukum, terjemahan Oetarid Sadino, Pradnya Paramita, Jakarta, 2001, p. 57

${ }^{4}$ Andi Hamzah. Korupsi di Indonesia Masalah dan Pemecahannya, Gramedia Pustaka Utama, Jakarta, 1991 , p. 2

${ }^{5}$ Adolfo Beria, Global Strategi Against Corruption, in Responding to Corruption: Social Defence, Corruption, and the Protection of Public Administration and The Independence of Justice, updated documens on the XIII International Conggres on Social Defence, Lecce Italy 1996, edited by Paolo Bernasconi, 2000, p. 23

${ }^{6}$ Ibid.

${ }^{7}$ Krisna Harahap, Pemberantasan Korupsi Jalan Tiada Ujung, Grafitri, Bandung, 2006, p. 15

${ }^{8}$ Andi Hamzah, Korupsi di Indonesia Masalah dan Pemecahannya, PT. Gramedia, Jakarta, 1984, p. 4

${ }^{9}$ Leden Marpaung, Tindak Pidana Korupsi Masalah dan Pemecahannya, Sinar Grafika, Jakarta, 1992, p. 149

${ }^{10}$ Pope, Jeremy, Strategi Memberatas Korupsi: Elemen Sistem Integritas Nasional, Yayasan Obor Indonesia, Yogyakarta, 2003, p. 3

${ }^{11}$ Evi Hartanti, Tindak Pidana Korupsi, Sinar Grafika, Jakrta, 2006, p. 2

${ }^{12}$ See https://acch.kpk.go.id/id/berkas/penindakan/penuntutan
} 
Number 30 Year 2002, while the investigation itself according to Article 1 number 3 is a series of investigative actions in terms of and according to the method stipulated in this law to search for and collect evidence with evidence that makes it clear about the crime that occurred and to find the suspect.

\section{Research Method}

Legal research according to Peter Mahmud Marzuki is a process to find the rule of law, legal principles, and legal doctrines to answer the legal issues faced. ${ }^{1}$ Moving on from understanding, this type of research is normative juridical research. Normative juridical research is a method of legal research conducted by examining library materials or mere secondary material. ${ }^{2}$

\section{Results and Discussion}

\section{A. Arrangements concerning Investigation of Corruption Crimes}

The authority to carry out investigations in criminal acts of corruption is owned by several state institutions, among others: the Police, the Attorney General's Office and the Corruption Eradication Commission (KPK), while the regulation regarding the investigation and investigation of corruption cases is regulated in several laws and regulations, among others: Law Number 2 Year 2002 concerning Indonesian Police, Law Number 16 Year 2004 concerning Prosecutors, Law Number 8 Year 1981 concerning Criminal Procedure Code, Law Number 30 Year 2002 concerning Corruption Eradication Commission, Law Number 31 Year 1999 jo Law Number 20 Year 2001 concerning Eradication of Corruption Crimes.

1. Arrangements in the Police Law.

Article 14 paragraph (1) letter g stipulates that "in carrying out the main tasks referred to in Article 13, the National Police of the Republic of Indonesia has the duty to conduct investigations and investigations into all criminal acts in accordance with criminal procedural law and other statutory regulations".

Given that a special KPK was established to eradicate Corruption Crime, the authority possessed by POLRI in investigating Corruption Crimes is limited to the authority possessed by the KPK, so the POLRI has the authority to investigate Corruption Crimes that do not involve law enforcement officials, state administrators, and other people relation to Corruption Crimes committed by law enforcement officials or State administrators, the authority to investigate Corruption Crimes that do not receive public attention; and/or the authority to investigate Corruption Crimes involving state losses of less than Rp. 1,000,000,000.00 (one billion rupiah).

2. Arrangements in the Prosecutor's Law

Article 30 paragraph (1) letter d of Law Number 16 Year 2004 concerning the Republic of Indonesia Prosecutor's Office states that in the criminal field, the Prosecutor's Office has the duty and authority of one of them concerning investigation, namely investigating certain criminal acts under the law, in which the authority is explained regarding authority as regulated for example in Law Number 26 Year 2000 concerning Human Rights Courts and Law Number 31 Year 1999 concerning Eradication of Corruption as amended by Law Number 20 Year 2001 jo. Law Number 30 Year 2002 concerning the Corruption Eradication Commission. Furthermore, Article 30 paragraph (1) letter e states that the duties and authorities of the other Prosecutors are to complete certain case files and for that they can carry out additional examinations before being delegated to the court which in coordination with the investigator.

3. Regulations in the Law of Corruption Eradication Commission

Law Number 30 Year 2002, the KPK has different powers than other law enforcement officers. In addition to being able to carry out the functions of investigation (functions that have been held by the Police), the KPK can also carry out the prosecution function (a function that has been held by the Prosecutor's Office). Based on certain reasons, the KPK was even given the authority to take over the process of investigation and prosecution of a criminal act of corruption that was previously handled by other law enforcement officials (the Police and Prosecutors) to be carried out by the KPK itself, according to the provisions stipulated in Article 6, Article 7 letter a, Article 8 paragraph (2), (3), (4), Article 9, Article 10, Article 11, Article 12, and Article 38 through Article 41.

\section{B. The Form of Speciality Investigations Performed by KPK}

The existence of the KPK as a structurally independent institution is not under executive control so that the KPK is not under the coordination of the President and is not under the auspices of the judukatif or legislative powers. In other words, the KPK is given the authority to carry out tasks in the field of prevention and law enforcement which are the executive's authority.

Komariah Emong Sapardjaja said that as an independent Agency, the KPK was classified as a State Commission. State commissions are often referred to in several different terms, for example in the United States known as administrative agencies. The so-called state commission is units of govermment created by statute to

\footnotetext{
${ }^{1}$ Peter Mahmud Marzuki, 2006, Penelitian Hukum, Kencana Prenada Media Group, Jakarta, p. 35

${ }^{2}$ Soerjono Soekanto and Sri Mamudji, Penelitian Hukum Normatif Suatu Tinjauan Singkat, Raja Grafindo Persada, Jakarta, 2007, p. 13
} 
carry out specific tasks in implementing tahune statute. Most administrative agencies fall in tahune executive branch, but some important agencies are independent. ${ }^{1}$ The definition of an independent state commission is a state organ which is idealized independently and therefore is outside the branch of executive, legislative and judicial powers; but it actually has the function of "tasting" all three. ${ }^{2}$ The independent commission often has quasi legislative, executive power and quasi judicial powers. ${ }^{3}$

The establishment of the KPK must be put in the context of extraordinary efforts to limit corruption and not and the KPK Law must be seen as a whole as a united spirit of corruption. In addition, the effectiveness of corruption prevention cannot be achieved only with available legal instruments. A clean government, where there are no or at least not many acts of corruption, cannot be realized only by legal regulations, even though it is a criminal law with sharp sanctions. The scope of the legal regulations is limited, so that the efforts to liberate can be carried out with actions in other fields other than the legal field, including political will from the government. ${ }^{4}$ The special characteristics of the KPK are as follows:

1. Taking Over Investigations from the Police and the Prosecutor's Office

The KPK Law Article 8 through Article 10 is determined as follows:

Article 8:

(1) In carrying out supervision duties as referred to in Article 6 letter b, the Corruption Eradication Commission is authorized to conduct supervision, research, or review of agencies that carry out their duties and authorities relating to the eradication of criminal acts of corruption, and agencies that carry out public services.

(2) In exercising the authority as referred to in paragraph (1), the Corruption Eradication Commission has the authority to take over the investigation or prosecution of the perpetrators of corruption committed by the police or the prosecutor's office.

(3) In the event that the Corruption Eradication Commission takes over the investigation or prosecution, the police or prosecutor's office must submit the suspect and all case files along with evidence and other documents required within a maximum of 14 working days, from the date of receipt of the Corruption Eradication Commission's request.

(4) Submission as referred to in paragraph (3) is carried out by making and signing the minutes of submission so that all duties and authorities of the police or prosecutor's office at the time of submission are transferred to the Corruption Eradication Commission.

Article 9 The transfer of investigation and prosecution as referred to in Article 8 shall be carried out by the Corruption Eradication Commission on the grounds:

a. Community reports on corruption acts are not followed up;

b. The process of handling corruption is prolonged or delayed without justifiable reasons;

c. The handling of criminal acts of corruption is intended to protect actual perpetrators of corruption;

d. Handling corruption acts contain elements of corruption;

e. Handling obstacles are not criminal corruption because of interference from the executive, judiciary or legislature; or

f. Other conditions which, according to the police or prosecutor's office, are detrimental to corruption in a manner that is difficult and accountable.

Article 10 In the event that there are reasons as referred to in Article 9, the Corruption Eradication Commission shall notify the investigator or public prosecutor to take over the criminal acts of corruption that are being handled. Then based on the provisions of Article 8, Article 9 and Article 10 above, the KPK has the authority to supervise, research or review the institutions that carry out their duties and authorities relating to the limitation of corruption, and instances in carrying out public services. Furthermore, if the KPK finds things according to the KPK "corruption cases are not continued, protracted or delayed, protect the real perpetrators, contain elements of corruption, have interference from other parties, other considerations or are wrong" then the KPK has the authority to take transfer of investigation or prosecution of perpetrators of corruption that is being carried out by the police or prosecutor's office.

Article 7 paragraph (2) concerning the Criminal Procedure Code stipulates that "Investigators as referred to in Article 6 paragraph (1) letter b have the authority in accordance with the law which becomes their respective legal basis and in carrying out their duties under the coordination and supervision of the investigator in Article 6 paragraph (1) letter a". What is meant by the investigator in Article 6 paragraph (1) letter a is the POLRI Official

\footnotetext{
${ }^{1}$ Komariah Emong Sapardjaja in giving his statement as an expert in the Decision of the Constitutional Court Number 012-016-019/PUUIV/2006 dated December 19, 2006, concerning the Testing of the Law of the Republic of Indonesia Number 30 Year 2002 concerning the Corruption Eradication Commission with 1945 Constitution of the Republic of Indonesia.

2 Jimly Asshiddiqie, Struktur Ketatanegaraan Indonesia Setelah Perubahan Keempat UUD Tahun 1945, paper in the seminar on Development of National Law VIII, Denpasar 14-18 July 2003

${ }^{3}$ Komariah Emong Sapardjaja, Op.Cit.

${ }^{4}$ Sudarto, Hukum dan Hukum Pidana, Bandung, Alumni, 1981, p. 124
} 
and what is meant by Article 6 paragraph (1) letter b is the official Civil Servants (PPNS) who are specifically authorized by law.

The authority to "take over" the investigations and prosecutions by the KPK from the police and prosecutors is a special matter in the process of investigation and prosecution. Even the KPK has the authority to take over investigations and prosecutions whose legal processes have not been completed before the formation of the KPK. This is clearly seen in the provisions of Article 68 of the KPK Law which formulates "All acts of investigation, investigation, and prosecution of criminal acts of corruption whose legal process has not been completed when the Corruption Eradication Commission is formed, can be taken over by the Corruption Eradication Commission based on the provisions referred to in Article 9.

2. Not issuing a termination of investigation or prosecution (SP3).

The KPK Law Article 40 states that "the Corruption Eradication Commission is not authorized to issue a warrant for the investigation and prosecution in cases of corruption". The provision shows that if there is a corruption case that has been investigated or prosecuted by the KPK, then the case will still be handed over to the trial, namely in the Corruption Court or TIPIKOR, meaning that someone who has been investigated or examined as a suspect by the KPK has also automatically become a defendant.

The Criminal Procedure Code states that the authority to hold an investigation by investigators is regulated in Article 7 paragraph (1) letter $\mathrm{i}$ in conjunction with Article 109 paragraph (2), while the authority to stop prosecution by the Public Prosecutor is regulated in Article 14 letter h jo. Article 140 paragraph (2).

Based on the provisions of Article 40 of the Corruption Eradication Commission Law above, it is desired by the legislators to not continue the investigation into the KPK to the level of investigation, especially prosecution, if the KPK is not yet sure that the evidence has been sufficient.

3. Conduct Investigation Against Officials Without Through Procedures stipulated in legislation.

Article 46 The KPK Law is explained as follows:

(1) In the event that a person is designated as a suspect by the Corruption Eradication Commission, starting from the date of stipulation, the special procedures applicable to the investigation of suspects stipulated in other laws and regulations do not apply under this Act;

(2) The examination of the suspect as referred to in paragraph (1), shall be carried out by not reducing the rights of the suspect.

Firmness of the provisions of Article 46 of the KPK Law above is a special provision which breaks the limits in carrying out investigative actions against suspects serving as Regional Heads or Legislative Members. This can be seen when the presence of Law Number 22 Year 1999 concerning Regional Government in Article 55 paragraph (1) regulates "Sanctions against the Regional Head are carried out after written approval from the President". Then in Article 28 paragraph (1) regulates the tentative action of investigating DPRD members with written approval from the Minister of Home Affairs for members of the Regional Representative Council and Governor for members of Regency and City DPRDs, except if the person is caught in crime".

The above provisions are further "strengthened" by the Regional Government Law, namely Law Number 32 Year 2004 concerning Regional Government, in Article 36 paragraph (1) concerning "The act of investigation and investigation of the Regional Head and/or Deputy Regional Head is carried out after written approval from the President at the request of the investigator". Then in Article 53 paragraph (1) which states "The act of investigation of DPRD members is carried out after written approval from the Minister of Home Affairs on behalf of the President for members of the Provincial DPRD and from the Governor on behalf of Domestic Meters for Regency/City DPRD members".

All investigative actions must be carried out with proof of proof at the trial, so that all evidence collected at the stage of investigation must be used to convince the Panel of Judges to prove the existence of an act of corruption. In this stage of the investigation the evidence of a corruption case was formulated, so that all the evidence obtained at this stage of investigation was used as "ammunition" for the Public Prosecutor to prove before the Panel of Judges that a criminal act of corruption had occurred. Therefore, the Criminal Procedure Code gives authority in the investigation phase in the form of forced efforts such as searches, seizures, arrests, and detention. However, with the provisions stipulated in Law Number 5 Year 1999 and Law Number 32 Year 2004 concerning Regional Government, a counter-productive thing arises in an effort to eradicate corruption in Indonesia.

4. Conduct Confiscation without Requiring a License/Approval from the Head of the Court.

KPK Law In the provisions of Article 47 explains:

(1) On the basis of strong suspicion that sufficient initial evidence is available, the investigator can carry out seizure without the permission of the Head of the District Court regarding the task of his investigation;

(2) The provisions of the applicable laws and regulations governing acts of seizure, do not apply under this Law.

Based on the provisions of Article 47 above, therefore the acts of seizure carried out by KPK Investigators in the investigation process can be carried out without the need for permission from the Head of the District 
Court. This is a privilege possessed by KPK investigators and is a very different deviation from the acts of seizure in force as stipulated in Article 38 of the Criminal Procedure Code.

5. Conduct Investigation and Prosecution

Article 7 paragraph (10) of the Criminal Procedure Code stipulates that the Investigator has the following authority:

a. Receive reports and/or complaints from someone about a crime;

b. Take the first action on the scene;

c. Asking to stop people who are suspected and asking questions and checking self-identification;

d. Conduct arrests, detention, searches and seizures;

e. Conduct inspection and seizure of letters;

f. Take fingerprints and photograph someone;

g. Call people to be heard and examined as suspects or witnesses;

h. Bring in experts who are needed in connection with the case examination;

i. Hold a termination of investigation;

j. Conduct other actions according to the law that are responsible.

Whereas the prosecution, based on Article 14 of the Criminal Procedure Code (KUHAP), the Public Prosecutor has the authority:

a. Receive and examine investigation case files from auxiliary investigators;

b. Conduct prapenutan what if there is a deficiency in the investigation by taking into account the provisions of Article 110 paragraph (3) and (4), by providing instructions in order to improve the investigation of the investigator;

c. Extending detention, carrying out detention or further detention and/or changing the status of detainees after the case is delegated by the investigator;

d. Making Indictments;

e. Delegate cases to the Court;

f. Submitting a notification to the defendant about the provisions of the day and time of the case being heard accompanied by a summons, both to the defendant and to the witness to come to the prescribed hearing;

g. Prosecuting;

h. Closing cases for legal purposes;

i. Hold other actions within the scope of duties and responsibilities as Public Prosecutors according to the provisions of the law;

j. Carry out the determination of the judge.

In the Corruption law it is determined that there are irregularities in the act of investigating the criminal acts of corruption, namely:

1) The investigator is authorized to ask the bank about the financial condition of the suspect or defendant (Article 29 paragraph (1) of the Corruption Law).

2) Investigators, Public Prosecutors, or judges can order banks to block savings accounts belonging to suspects or defendants suspected of resulting from corruption (Article 29 paragraph (4) of the Corruption Law).

3) Investigators have the right to open, inspect and confiscate letters and shipments by post, telecommunications, or other equipment suspected of having a relationship with the case of corruption that is being examined (Article 30 of the Corruption Law).

4) In the event that the investigator finds and argues that one or more elements of a criminal act of corruption do not have enough evidence, while there has been a state loss, the investigator immediately submits the results of the investigation to the State Attorney for civil claims or is handed over to the aggrieved agency to file a lawsuit (Article 32 paragraph (1) of the Corruption Law).

5) In the event that a suspect dies during an investigation, while there is a real loss of state finances, the investigator will immediately submit the case file of the investigation to the State Attorney Attorney or be handed over to the injured party to do a civil suit against the heirs (Article 33 Corruption Law). follows:

The article must also be considered, namely Article 26 A of the Corruption Law which states as

Valid Evidence in the form of instructions as referred to in Article 188 paragraph (2) of Law Number 8 of 1981 concerning Criminal Procedure Law, specifically for Corruption Crime can also be obtained:

a. Other Evidence in the form of information that is said, sent, received, or stored electronically with an optical instrument or similar to that; and

b. Documents, namely every record of data or information that can be seen, read and or heard that can 
be issued with or without the help of a facility, whether written on paper, physical objects or paper, or electronically recorded, in the form of writing, sound, images, maps, designs, photos, letters, signs, numbers, or perforations that have meaning.

Based on the provisions of Article 26 A of the above Corruption Law, the evidence in the case of a Corruption Crime case is not only obtained from witness statements, letters and statements of defendants as stipulated in Article 188 paragraph (2) of the Criminal Procedure Code (KUHAP). But it can also be obtained from information and documents in the form of existing technological advances.

6. Tapping and Recording Conversations

One that is also the authority of the Corruption Eradication Commission which is special and not owned by the Police and the Prosecutor in conducting corruption cases. This is stated in Article 12 point a of the KPK Law which states that in carrying out investigative duties, investigating and prosecuting corruption, KPK is authorized:

a. Tapping and recording conversations;

b. Order the relevant agencies to prohibit someone from traveling abroad;

c. Request information from the bank or other financial institution about the financial condition of the suspect or defendant being examined;

d. Instruct banks or other financial institutions to block accounts suspected of being the result of corruption belonging to the suspect, defendant, or other related parties;

e. Order the leader or superior of the suspect to temporarily dismiss the suspect from his position;

f. Requesting the suspect or defendant's wealth data and tax data to the relevant agencies;

g. Temporarily stop a financial transaction, trade transaction, and other agreements or temporary revocation of licenses, licenses and concessions that are carried out or owned by a suspect or defendant allegedly based on sufficient initial evidence relating to the criminal act of corruption being examined;

h. Request assistance from Interpol Indonesia or other state law enforcement agencies to conduct searches, arrests and seizures of evidence abroad;

i. Requesting police assistance or other related institutions to conduct arrests, detention, searches and seizures in cases of corruption that are being handled.

From the above provisions, it can be seen that the KPK has the authority to establish and record conversations with people suspected or suspected of committing corruption without having to ask permission from certain parties. According to Mansur Kartayasa, this authority has a positive effect on disclosure of corruption cases that are increasingly increase, so that the authority of this extraction needs to be maintained but must be done with good ethics, which is solely aimed at uncovering cases of corruption and not entering the personal realm of the respective indifid who can reduce freedom and independence in carrying out daily life. ${ }^{1}$ Tapping can be classified into two categories, 1. Tapping on time, 2. Tapping is not on time, which is called tapping available data (retained data). ${ }^{2}$

Provisions regarding banning tapping stipulated in Article 40 of Law 36 Year 1999 concerning Telecommunications do not apply in the sense that it is not a criminal offense, nor is the obligation to carry out telecommunication services to keep information sent or received by customers of telecommunications services regulated in Article 42 Law 36 Year 1999, is not valid or can be stored for the benefit of the criminal justice process; but there are conditions that must be fulfilled, namely telecommunication service providers can provide information needed if they are:

a. There is a written request from the Attorney General and or the National Police Chief for certain criminal acts;

b. Requests for investigators for certain criminal acts in accordance with applicable laws.

With the provisions regarding prohibitions on seduction and procedures that must be taken in making the preparation for the interests of the criminal justice process, it is necessary to harmonize various laws and regulations, especially between Law Number 30 Year 2002 concerning the Corruption Eradication Commission which regulates the authority of the Corruption Eradication Commission. with Law No. 39 Year 1999 which regulates the prohibition of sedimentation, the obligation to carry out telecommunications to maintain the confidentiality of information sent and received as well as procedures that must be taken in the interests of the criminal justice process in conducting flavoring. This harmonization requires that on the one hand the disclosure of corruption cases does not experience obstacles in terms of procedures and procedures for sedimentation, on the other hand to prevent attempts to delegitize the wiretapping authority of the KPK through lawsuits in the judiciary and the Constitutional Court in the name of freedom of information and human rights Human.

Every state loss caused by perpetrators of corruption, both those that are still in the country and those

\footnotetext{
${ }^{1}$ Mansur Kartayasa, Korupsi \&Pembuktian Terbalik Dari Prespektif Kebijakan Legislasi dan Hak Asasi Manusia, Kencana, Jakarta, 2017, p. 342

${ }^{2}$ Munir Fuady and Sylvia Laura L. Faudy, HakAsasiTersangkaPidana, Prenada Media Group, Jakarta, Edisi Pertama, 2015, p. 286
} 
already outside the country must be returned, through the mechanism of international cooperation which is an absolute thing to do. ${ }^{1}$ Law is not just a collection or sum of regulations, each of which stands alone, but is also a legal system, ${ }^{2}$ must start from the upper power class and upper economic class by paying attention to the principles of presumption of innocence, ${ }^{3}$ related to that, according to Mansur Kartayasa that the need for haromization between Law Number 30 Year 2002 concerning the Corruption Eradication Commission regulates the authority of the Corruption Eradication Commission to make provisions with Law Number 39 Year 1999 concerning Telecommunications and Law Number 11 Year 2008 concerning Information and Electronic Transactions. ${ }^{4}$

\section{Conclusion}

The privilege of conducting investigations by the Corruption Eradication Commission in eradicating corruption is the abolition of the basic principles of the Criminal Procedure Code that highly uphold the rights of suspects and human rights. In addition, in order to create a good investigation process in the integrated Criminal Justive System, there is a need for harmonization in formal law (procedural law) as a basis in the case inspection process in order to create a harmonious implementation of the duty to limit corruption.

\section{References}

Andi Hamzah. Korupsi Di Indonesia Masalah dan Pemecahannya. GramediaPustaka Utama, Jakarta, 1991

Andi Hamzah, Korupsi di Indonesia Masalah dan Pemecahannya, PT. Gramedia, Jakarta, 1984

Andi Sofyan and Nur Azisa, Hukum Pidana, Pustaka Pena Press, Makassar, 2016.

Anonimous, Pedoman Pelaksanaan Kitab Undang-Undang Hukum Acara Pidana, Penerbit Departemen Kehakiman Republik Indonesia, 1982

Barda Nawawi Arief, Kapita Selekta Hukum Pidana tentang Sistem Peradilan Pidana Terpadu, BP Universitas Diponegoro Semarang, 2007.

Evi Hartanti, Tindak Pidana Korupsi, Sinar Grafika, Jakrta, 2006.

Global Strategi Against Corruption, dalam Responding to Corruption: Social Defence, Corruption, and the Protection of Public Administration and The Independence of Justice, updated documens on the XIII International Conggres on Social Defence, Lecce Italy 1996, edited by Paolo Bernasconi, 2000.

Haeranah, Ganti Kerugian Bagi Terangka, Terdakwa, Terpidana dalam Perspektif Hak Asasi dan Tanggung Jawab Negara, Pustaka Pena Press, Makassar.

https://acch.kpk.go.id/id/berkas/penindakan/penuntutan

Indriyato Seno Adji, Korupsi dan Penegakan HUkum, Diadit Media, Jakarta, 2009.

Jack Donnelly, Universal Human Rights in Theory and Practice, $2^{\text {nd }}$ ed., Cornel University Press, Itacha.

Jimly Asshiddiqie, Struktur Ketatanegaraan Indonesia Setelah Perubahan Keempat UUD Tahun 1945, paper in the seminar on Development of National Law VIII, Denpasar 14-18 July 2003.

Kadarudin, Asset Recovery Hasil Kejahatan Korupsi: Upaya Pengembalian Kerugian Keuangan Negara Melalui Kerjasama Internasional, Pustaka Pena Press, Makassar, 2015.

Komariah Emong Sapardjaja in giving his statement as an expert in the Decision of the Constitutional Court Number 012-016-019/PUU-IV/2006 dated December 19, 2006, concerning the Testing of the Law of the Republic of Indonesia Number 30 Year 2002 concerning the Corruption Eradication Commission with the 1945 Constitution of the Republic of Indonesia.

Krisna Harahap, Pemberantasan Korupsi Jalan Tiada Ujung, Grafitri, Bandung, 2006.

L.J. van Apeldoorn, Pengantar Ilmu Hukum, terjemahan Oetarid Sadino, Pradnya Paramita, Jakarta, 2001.

Leden Marpaung, Tindak Pidana Korupsi Masalah dan Pemecahannya, Sinar Grafika, Jakarta, 1992

Lilik Mulyadi, Hukum Acara Pidana (SuatuTinjauan KhususTerhadap Surat Dakwaan, Eksepsi, dan Putusan Peradilan), Penerbit PT Citra Aditya Bakti, Bandung, 2002.

Lilik Mulyadi, Hukum Acara Pidana Normatif, Teoretis, Praktik Dan Permasalahannya, Alumni, Bandung, 2007.

M. Said Karim, Ganti Kerugian Terhadap Korban Penangkapan yang Tidak Sah dalam Proses Peradilan Pidana, Pustaka Pena Press, Makassar, 2019.

Mansur Kartayasa, Korupsi \&Pembuktian Terbalik Dari Prespektif Kebijakan Legislasi dan Hak Asasi Manusia, Kencana, Jakarta, 2017.

Maurice Cranston, What Are Human Rights, Taplinger Publishing Co. 1973

Mc Inenrney-Lankford Siobhan, Sano Otto-Hans., Human Rights Indicators in Development: An Introduction,

${ }^{1}$ Kadarudin, Asset Recovery Hasil Kejahatan Korupsi: Upaya Pengembalian Kerugian Keuangan Negara Melalui Kerjasama Internasional, Pustaka Pena Press, Makassar, 2015, p. 87

${ }^{2}$ Sudikno Mertokusumo, Mengenal Hukum, Suatu Pengantar, Liberty, Yogyakarta, 1966, p. 108

${ }^{3}$ Indriyato Seno Adji, Korupsi dan Penegakan Hukum, Diadit Media, Jakarta, 2009, p. 66 - 68

${ }^{4}$ Mansur Kartayasa, Op.Cit. 
The World Bank, Washington D.C., PCS Country Services, Nordic Trust Fund. 2003.

Munir Fuady dan Sylvia Laura L. Faudy, Hak AsasiTersangka Pidana, Prenada Media Group, Jakarta, 2015

Nur Azisa, Nilai Keadilah Terhadap Jaminan Kompensasi Bagi Korban Kejahatan (Sebuah Kajian Filospfis Normatif), Pustaka Pena Press, Makassar, 2016.

Peter Mahmud Marzuki, Penelitian Hukum, cet.2, Kencana Prenada Media Group, Jakarta. 2006,

Pope, Jeremy, Strategi Memberatas Korupsi: Elemen Sistem Integritas Nasional, Yayasan Obor Indonesia, Yogyakarta, 2003

Sudarto, Hukum dan Hukum Pidana, Bandung, Alumni, 1981

Soerjono Soekanto and Sri Mamudji, Penelitian Hukum Normatif Suatu Tinjauan Singkat, Raja Grafindo Persada, Jakarta, 2007

Sudikno Mertokusumo, Mengenal Hukum, Suatu Pengantar, Liberty, Yogyakarta, 1966.

Tolib Setiady, Pokok-Pokok Hukum Panitensier Indonesia, Alfabeta, Bandung, 2010. 